\title{
Kiril Taranovsky and his Greatest Work
}

\section{Mihhail Lotman, Igor Pilshchikov*}

The name Kiril Taranovsky (1911-1993) has much less acclaim outside the Slavic world than it deserves. Even his book on Mandelshtam, which was published in English in 1976, mainly attracted the attention of Slavists as the first systematic description of the poetics of an author whose works are so famously difficult to understand. But the methods of contextual and subtextual analysis that Taranovsky developed, and his insights on literary theory, are no less significant (see Levinton, Timenchik 1978). Taranovsky's findings are important for the theory of intertextuality and can serve as a link between literary studies and linguistic pragmatics (Lotman 1984).

In one key aspect, Taranovsky's approach differs from that adopted in Western literary criticism: not only the theme of a work (its subject matter, setting, imagery, etc.) but any component of its structure, including the verse structure, can be treated as a subtext. On the one hand, Taranovsky continues the traditions of Russian Formalism; on the other hand, he draws on his own research into the structure and semantics of Russian verse. By the time Taranovsky undertook his research on Mandelshtam's poetics, he had not only done an enormous amount of work in describing poetic rhythm (Taranovsky 1953, 1955/1956) but he had also outlined a new field in Russian verse theory: the semantics of poetic meter (Taranovsky 1963) and rhythm (Taranovsky 1966). His contribution to Slavic studies was testified by a collection of essays dedicated to him in honor of his 60th birthday, with items from 51 colleagues and former students (see Jakobson, Schooneveld, Worth 1973).

Kirill Fedorovich Taranovsky was born in Yuriev, now Tartu in Estonia; his father, a jurist, was a professor of law at the University of Tartu. The revolution put an end to this comfortable life, however, and the family emigrated through the Crimea and Turkey to the Balkans. Taranovsky spent his youth in Serbia and was deeply integrated into the culture of the country; in particular, he translated Russian classics into Serbian. He earned a degree in Slavic languages from the University of Belgrade in 1936 and then defended his doctoral thesis

\footnotetext{
* Authors' addresses: Mihhail Lotman, Department of Semiotics, University of Tartu, Jakobi 2, 51014 Tartu, Estonia, e-mail: mihhail.lotman@gmail.com; Igor Pilshchikov, University of California, Los Angeles, Department of Slavic, East European and Eurasian Languages and Cultures, 320 Kaplan Hall, UCLA, Los Angeles, CA 90095; Tallinn University, School of Humanities, Uus-Sadama 5, Tallinn 10120, Estonia, email: pilshch@tlu.ee.
} 
there, written under the supervision of the famous Slavist Aleksandar Belić, in 1941. It formed the foundation of his greatest work, Ruski dvodelni ritmovi (Russian Binary Meters).

This book had a complicated fate due to the Second World War; a bomb hit the printing house where the book was being prepared for publication and the entire print run was destroyed. It took more than a decade to restore the text and the book only saw the light of day as late as 1953. As Taranovsky himself told one of the authors of this note, the delay had some positive effects, since over the years he was able not only to supplement his original material, but also to connect it with the ideas of Nikolai Trubetzkoy and Roman Jakobson.

Taranovsky's study consists of two parts. The main bulk of the book is the second part, which contains a description of the rhythm of Russian binary meters in its historical development. Jakobson and Trubetzkoy defined Russian meters in terms of binary oppositions (Lotman 2013), but Taranovsky proposed a more refined approach based on statistical data. Jakobson distinguished between rhythmical constants (the basis of meter), rhythmical tendencies (the basis of rhythmical impulse) and the autonomous elements of rhythm (Jakobson 1979 [1930]), whereas Taranovsky discerns metrical constants (compulsory stress on the last strong position in the verse line), dominants (absence of verbal stress on weak positions), and rhythmic tendencies (stress on strong positions). These concepts have become well established in poetics and are now used to describe both Russian and non-Russian verse (Lotman, Lotman 2018).

The second part of Taranovsky's book is immeasurably richer in statistical material than the first part, which, however, contains more theoretical insights and offers a more multifaceted model for describing verse than the simplified and reductionist version of the same model implemented in the second part. Thus, as Michael Wachtel pointed out, "the more famous second part (on [...] the evolution of rhythmic patterning in various meters) does not fully take into account the observations of the first part (on accentuation in Russian verse). In particular, two elements are missing from the second part: the role of hypermetrical stress and the relative strength of stresses on strong syllables. Taranovsky recognized these phenomena, but they are nowhere reflected in his statistical data and conclusions" (Wachtel 2015: 192-193). ${ }^{1}$ To this we can add the statistics of word-boundaries: they are discussed in Part One, but only the constant word-boundaries (caesurae, or "medians", as Taranovsky calls

1 Abstract in Russian. The English text is quoted from https://www.sciencegate.app/doi/ abs/10.30851/59.2.001 (accessed January 5, 2021). 
them, following Georgy Shengeli) are taken in consideration in Part Two. The statistics of word-boundaries are included in the Appendices but not interpreted in the main text - perhaps because Taranovsky was unable to identify any meaningful tendencies.

Taranovsky's connection to Jakobson went beyond scholarly engagement; the two met in Prague in the 1930s and maintained a long-term friendship that stretched through the 1960s when both scholars were professors at Harvard University's Department of Slavic Languages and Literatures. In 1973, Jakobson was one of the editors of the Taranovsky Festschrift. After Russian Binary Meters was published in 1953, Jakobson reviewed his future colleague's work favorably:

The author of this book, an outstanding Slavic philologist, has made important contributions to the study of Slavic versification. [...] The new monograph is devoted to the Russian binary meters, trochee and iamb: the first part deals with their invariable foundations, while the second carefully traces the rise and evolution of these verse forms within the last two centuries, with a generous use of statistical calculations. [...] Taranovsky's study exhaustively treats the role of the word-stress in the Russian binary meters throughout the last two centuries of their evolution [...] Such a focusing on one problem enables the author to detect the cardinal rhythmical peculiarities of different epochs, poetic schools, individual poets and poems [...] Taranovsky's book thoroughly reveals the manifold play of the word-stress in Russian binary meters (Jakobson 1955: 644-646).

After a few considerations regarding phrase-accent, Jakobson concluded his review with a call for further elaboration: "Now it is from him that we expect also the next chapter, a syntactic phonology of these verse forms" (1955: 646). Such a book was never written either by Taranovsky or anyone else.

Mikhail Gasparov, representing the next generation of outstanding scholars of verse after Taranovsky, gave the following concise contextualization of Russian Binary Meters:

In order to appreciate the significance of K. F. Taranovsky's principal work, we must recall the state of Russian versification scholarship in the 1930s, when the first wave of verse studies, initiated by Andrei Belyi, subsided. On the one hand, there existed statistical studies of the rhythm of particular meters used by individual authors, exemplary in accuracy but very few in number (mainly the works of B. Tomashevsky). On the other hand, there existed a general concept of the phonological basis of Russian verse meters, developed by R. Jakobson and N. Trubetzkoy, which was not, however, tested on sufficiently large statistical 
material. Taranovsky's book bridged the gap between these two achievements of Russian poetics. What Tomashevsky did for a few dozen thousand 4- and 5-iambic lines of Pushkin and his contemporaries, Taranovsky did for 300,000 lines of all the iambic and trochaic meters from Lomonosov to Fet. As a result of this titanic work, it became possible to give concrete statistical meaning to the concepts of rhythmic constants, dominants and tendencies introduced by Jakobson and Trubetzkoy. It also became possible to formulate two basic laws of the rhythm of Russian binary meters, the law of regressive accentual dissimilation (alternation of strong and weak feet from the end of the line to the beginning) and the law of the ascending rhythmic tilt (stabilization of the first ictus after the first temps faible in the verse line). This was a solution to the problem of meter and rhythm that twentieth-century Russian verse theory was persistently faced with. All modern studies of the rhythm of Russian binary meters cannot but proceed from the concepts established by Jakobson and Trubetzkoy, and from the laws established by Taranovsky (Gasparov 1971: 545).

In his review of Russian Binary Meters, Jakobson insisted that "Taranovsky's laws" and their dynamics are "due to the interaction of the structural properties of Russian verse and may hardly be explained by the mechanical influence of other meters, folklore or foreign models" (Jakobson 1955: 646). This was a principally novel approach to the evolution of verse, albeit one that continued in the tradition of Russian verse studies as pioneered by Andrei Belyi (1910) and developed by Georgy Shengeli (1923) and Boris Tomashevsky (1929). In his groundbreaking studies, Andrei Belyi established that the main factor of the rhythm of Russian iambs is the presence or absence of stress on strong positions: the eighteenth- and nineteenth-century rhythms are fundamentally different from each other. When Belyi arrived at this conclusion, he deliberately abstracted from the other phonic features of verse that he also identified. This narrow focus on the (un)stressedness of strong positions became an object of criticism: Valery Briusov (1910) reproached Belyi for not taking into account extra-schematic stresses and word-boundaries, and Viktor Zhirmunsky (1925: 90-95) critiqued him for not differentiating stresses by their strength. Later Vadim Baevsky $(1968,1969)$, as well as Andrei Kolmogorov and Aleksandr Prokhorov (1968) tried to formalize the differentiation of stresses according to their strength, but these attempts did not result in either a typology of rhythmical forms or an analysis of the evolution of rhythm. Gasparov preferred to return to the tradition of Shengeli, Tomashevsky and Taranovsky.

Taranovsky's work is still in common use today. Even researchers such as Sergei Liapin (see his article in this issue of Studia Metrica et Poetica), who develop a fundamentally different concept of the evolution of Russian rhythm, 
have to constantly compare their results with those of Taranovsky's classic study. At the opening of the international conference Slavic Verse in Moscow in 1995, Mikhail Gasparov maintained that the major issues in describing Russian rhythm have already been solved: "The four traditional areas of verse studies - meter, rhythm, rhyme, and stanza - are already so well developed that no new revolutions are expected in the near future"; "the research methodology has already been established, and all that is needed is time and capable graduate students" (Gasparov 1996: 5). The studies of the next generation of verse theorists (first and foremost, Liapin; see also Golovastikov 2010) show that this is not at all undisputable and we will have much to revise and reconsider from Taranovsky's conclusions. However, we have every reason to believe that the rhythmic patterns described by Taranovsky have even more general significance. They are manifested on the phrasal (Jakobson 1955) and stanzaic level (Gasparov 1989, Lotman 2014, Scherr 2017), and even in the rhythm of non-Russian poetic traditions (Lotman 2019).

Taranovsky's book, written in Serbian, was for a long time available only to the limited number of Slavists who could cope with language difficulties while reading it. This classic work was only published in Russian fairly recently (Taranovsky 2010). The English translation by Walter Vickery and Lawrence Feinberg, the first part of which is now placed before readers, was made much earlier but has never before seen the light of day. Professor Feinberg describes the history of this translation in the foreword to this publication.

Walter N. Vickery (1921-1995) was a British and American scholar of Russian literary history and Russian verse. He authored literary biographies of Pushkin (1970) and Lermontov (1995, published posthumously), and a study of Pushkin's duel and death (The Death of a Poet, 1968). Remarkably, his research papers on Pushkin were published both in America and in Russia, a rather rare case in Pushkin scholarship. Vickery's studies of Russian verse include the rhythm of Pushkin's iambic pentameter without caesura (in the International Journal of Slavic Linguistics and Poetics, 1971), Russian iambic hexameter and its relation to French alexandrine verse (in American Contributions to the Seventh International Congress of Slavists, 1973), the stanzaic structure of Pushkin's "Recollections in Tsarskoe Selo" and "The Monument" (in the Taranovsky Festschrift, 1973), and the attributive adjectives in Lermontov's poetry (in Russian Verse Theory, 1989). Together with Edward Stankiewicz he edited and wrote an introduction to the Anglophone edition of Viktor Zhirmunsky's Introduction to Metrics: The Theory of Verse (1966). 


\section{References}

Baevsky, Vadim Solomonovich 1968. Ob eksperimental'nom issledovanii russkogo stikha al'ternirujushchego ritma. In: Metody eksperimental'nogo analiza rechi: Tezisy dokladov k Respublikanskomu simpoziumu... (21-23 ijunja 1968 g.). Minsk: MGPIIYa, 16-22.

Baevsky, Vadim Solomonovich 1969. Stikh al'ternirujushchego ritma v svete auditorskogo eksperimenta. In: Petrosov, Konstantin Grigor'evich (ed.), Russkaja sovetskaja poezija i stikhovedenie. Moskva: MOPI imeni N. K. Krupskoj, 244-250.

Belyi, Andrei 1910. Simvolizm: Kniga statej. Moskva: Musaget.

Briusov, Valery Yakovlevich 1910. Ob odnom voprose ritma (po povodu knigi Andreja Belogo “Simvolizm”). In: Apollon 11, 52-60.

Gasparov, Mikhail Leonovich 1971. K 60-letiju K. F. Taranovskogo. In: Uchenye zapiski Tartuskogo universitetata 284 (Trudy po znakovym sistemam / Works on Semiotics ( Tööd semiootika alalt V). Tartu: Tartu Ülikooli Kirjastus, 545-546.

Gasparov, Mikhail Leonovich 1989. Stroficheskij ritm v russkom 4-stopnom jambe i khoree. In: Scherr, Barry P.; Worth, Dean S. (eds.), Russian Verse Theory: Proceedings of the 1987 Conference at UCLA. Columbus, Ohio: Slavica, 133-147.

Gasparov, Mikhail Leonovich 1996. Lingvistika stikha. In: Gasparov, Mikhail Leonovich; Skulacheva, Tatyana Vladimirovna (eds.), Slavjanskij stikh: Stikhovedenie, lingvistika i poetika: Materialy mezhdunarodnoj konferentsii, 19-23 ijunja 1995 g. Moskva: Nauka, 5-17.

Jakobson, Roman 1955. Review of Taranovsky, Kiril. Ruski dvodelni ritmovi I-II. Beograd: Naučna knjiga, 1953. In: Word 11(4), 644-647.

https://doi.org/10.1080/00437956.1955.11659582 [Republished as "Russian Binary Meters" in: Jakobson, Roman 1979. Selected Writings. Vol. 5: On Verse, Its Masters and Explorers. The Hague, Paris: Mouton, 167-169.]

Jakobson, Roman 1979 [1930]. On Translation of Verse. In: Jakobson, Roman. Selected Writings. Vol. 5: On Verse, Its Masters and Explorers. The Hague, Paris: Mouton, $131-134$.

Jakobson, Roman; Schooneveld, Cornelis H. van; Worth, Dean S. (eds.) 1973. Slavic Poetics: Essays in honor of Kiril Taranovsky. The Hague, Paris: Mouton.

Kolmogorov, Andrei Nikolaevich; Prokhorov, Aleksandr Vladimirovich 1968. K osnovam russkoj klassicheskoj metriki. In: Meylakh, Boris Solomonovich (ed.), Sodruzhestvo nauk i tajny tvorchestva. Moskva: Iskusstvo, 397-432. 
Levinton, Georgy Akhillovich; Timenchik, Roman Davidovich 1978. Kniga K. F. Taranovskogo o poezii O. E. Mandel'shtama. In: Russian Literature 6(2), 197-211.

Liapin, Sergei Evgen'evich 2020. Russian Iambic Tetrameter: The Evolution of Its Rhythmic Structure. In: Studia Metrica et Poetica 7(2), 7-22.

Lotman, Mihhail 1984. Semantika konteksta i podteksta v poezii Mandel'shtama. In: International Journal of Slavic Linguistic and Poetics 29, 133-142.

Lotman, Mihhail 2013. Formalizm i strukturalizm v stikhovedcheskikh shtudijakh Romana Jakobsona. In: Russkij formalizm (1913-2013): Mezhdunarodnyj kongress k 100-letiju russkoj formal'noj shkoly. Moskva, 25-29 avgusta 2013: Tezisy dokladov. Moskva: Institut slavjanovedenija RAN, 223-225.

Lotman, Mihhail 2014. Ritmicheskaja struktura oneginskoj strofy i problemy stroficheskogo ritma. In: Scherr, Barry P.; Bailey, James; Johnson, Vida T. (eds.), Poetry and Poetics: A Centennial Tribute to Kiril Taranovsky. Bloomington, Ind.: Slavica, 61-89.

Lotman, Mihhail 2019. The semiotics of verse rhythm and comparative rhythmics: Vladimir Nabokov's and Jurgis Baltrušaitis's binary tetrameters from a typological perspective. In: Studia Metrica et Poetica 6(2), 74-101.

https://doi.org/10.12697/smp.2019.6.2.03

Lotman, Mihhail; Lotman, Maria-Kristiina 2018. Eesti silbilis-rõhulise rütmika jooni: neliktrohheus ja -jamb 19. sajandi teisel poolel ja 20. sajandi alguses. Tallinn: EKSA.

Scherr, Barry P. 2017. Analyzing Stanza Rhythm in Russian Poetry: A Brief History and Future Directions. In: Akimova, Marina Vjacheslavovna; Tarlinskaja, Marina (eds.), M. L. Gasparovu-stikhovedu in memoriam. Moskva: Jazyki slavjanskoj kul'tury, 117-137.

Shengeli, Georgy Arkadievich 1923. Traktat o russkom stikhe. Chast' 1: Organicheskaja metrika. Izdanie 2-e, pererabotannoe. Moskva, Petrograd: Gosudarstvennoe izdatel'stvo.

Taranovsky, Kiril [Kirill Fedorovich] 1953. Ruski dvodelni ritmovi I-II. Beograd: Naučna knjiga.

Taranovsky, Kiril [Kirill Fedorovich] 1955/1956. Ruski četvorostopni jamb u prvim dvema decenijama XX veka. In: Južnoslovenski filolog 21(1/4), 15-43. 
Taranovsky, Kiril [Kirill Fedorovich] 1963. O vzaimootnoshenii stikhotvornogo ritma i tematiki. In: American Contributions to the Fifth International Congress of Slavists: Sofia, September 1963. Vol. 1: Literary Contributions. The Hague: Mouton \& Co., 287-332.

Taranovsky, Kiril [Kirill Fedorovich] 1966. Chetyrekhstopnyj jamb Andreja Belogo. In: International Journal of Slavic Linguistic and Poetics 10, 127-147.

Taranovsky, Kiril [Kirill Fedorovich] 1976. Essays on Mandel'štam. Cambridge, Mass., and London: Harvard University Press.

Taranovsky, Kiril [Kirill Fedorovich] 2010. Russkie dvuslozhnye razmery. Stat'i o stikhe. Son'kin, Viktor Valentinovich (tr.). Moskva: Jazyki slavjanskoj kul'tury.

Tomashevsky, Boris Viktorovich 1929. O stikhe. Leningrad: Priboj.

Wachtel, Michael 2015. Charts, Graphs, and Meaning: Kiril Taranovsky and the Study of Russian Versification. In: Slavic and East European Journal 59(2), 178-193. https://doi.org/10.30851/59.2.001

Zhirmunsky, Viktor Maksimovich 1925. Vvedenie v metriku: Teorija stikha. Leningrad: Academia. 